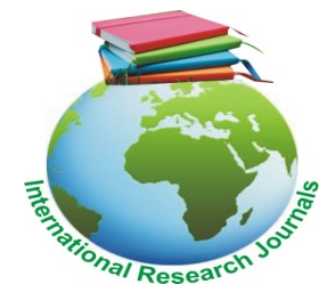

African Journal of Food Science and Technology (ISSN: 2141-5455) Vol. 6(6) pp. 144-148, September, 2015 Available online @http://www.interesjournals.org/AJFST

Full Length Research Paper

\title{
Moisture adsorption of sprouted bambara groundnut flour (Vigna subterranean)
}

\author{
${ }^{* 1}$ Oguntoyinbo, S. I., ${ }^{1}$ Okewande, O. W., ${ }^{3}$ Nupo, S. S., ${ }^{1}$ Sobowale, S. S., ${ }^{4}$ Ajayi, J.O., \\ ${ }^{1}$ Odunmbaku, L. A. and ${ }^{2}$ Oguntoyinbo, Y. G. \\ ${ }^{1}$ Department of Food Technology, Moshood Abiola Polytechnic, Abeokuta, Ogun State, Nigeria \\ ${ }^{2}$ Nutrition and Dietetics Unit, School of Nursing Ilaro, Ogun State, Nigeria. \\ ${ }^{3}$ Department of Nutrition and Dietetics, Moshood Abiola Polytechnic, Abeokuta, Ogun State, Nigeria. \\ ${ }^{4}$ Science Technology Department, Moshood Abiola Polytechnic, Abeokuta, Ogun State, Nigeria. \\ *Corresponding Author’s E-mail: graceyetty2020@gmail.com; graceyetty@yahoo.com
}

\begin{abstract}
This study investigated the moisture adsorption characteristics of sprouted Bambara groundnut (Vigna subterranean). The adsorption isotherm for sprouted Bambara groundnut was determined and studied at room temperature $\left(27 \pm 2{ }^{\circ} \mathrm{C}\right)$ using the static gravimetric method. Samples were equilibrated in desiccators containing tetraoxosulphate (VI) acid solution of known relative humidity varied from $20 \%$, $30 \%, 40 \%$ and $50 \%$. The moisture content was then calculated using the data of initial moisture content and the amount of moisture gained or lost at equilibrium. The desiccators were made into each relative humidity and were studied at room temperature $\left(27 \pm 2{ }^{\circ} \mathrm{C}\right)$. The plot of equilibrium moisture content against water activity at $20 \%, 30 \%, 40 \%$ and $50 \%$ for adsorption process gave a sigmoidal shaped isotherm curve. The equilibrium moisture content value increased with water activity. The Henderson and Oswin models gave the best fit and could be used to present the moisture adsorption isotherm of sprouted bambara groundnut flour for water activity content range of 0.2 to 0.5 .
\end{abstract}

Keywords: Sprouted bambara groundnut, moisture adsorption, equilibrium moisture content, relative humidity

\section{INTRODUCTON}

Moisture sorption isotherms are useful thermodynamic tools for determining the interaction of water and food substances. They also provide information for assessing food processing operations, such as drying, mixing, packing and storage. Such data can be used for selecting appropriate storage conditions and packing systems that optimize or maximize the retention of aroma, colour, texture, nutrients and biological stability (Labuza et al, 1985 and Rizvi, 1995). Moisture sorption isotherms show the dependence of the water content on the water activity (aw) of a food at a definite temperature and pressure.

The knowledge of water activity is a better indicator in understanding the storage stability of food materials than water content, but the knowledge of moisture alone is not sufficient to predict the stability of foods. The quality of most food materials preserved by drying depends largely on their physical, chemical and microbiological stability. At constant temperature, the moisture content of the food changes until it reaches an equilibrium with the water vapour of the surrounding air. The movement of water vapour from the food material to the surrounding air depends on the food material and the condition of the surrounding air (temperature and humidity).

Food legumes have a major role to play in the fight against malnutrition. It is therefore necessary that their levels of consumption, which are too low in a number of developing countries, should be increased. Legumes serve as a source of protein to a large proportion of the population in the poor countries of the world by being the least expensive and easily stored and transported non processed protein source for rural and urban dwellers (Rachie and Silvester, 1977). The high carbohydrate 
(65\%) and relatively high protein (18\%) content of Bambara groundnut make it a complete food.

Sprouting seeds of most cereals and legumes have shown improvements in nutrients in human diet and compare well with their fresh counterparts if not better (Kakade and Evans, 1966; Kylen and McCready, 1975). Studies have shown that although legumes are known for their high protein content, their utility is limited because of the low protein digestibility. A combination of sprouting and cooking resulted in an excellent digestibility coefficient (El-Hag et al., 1978; Ologhobo and Fetuga, 1986). Germination resulted in greater retention of all minerals and B-complex vitamins compared to cooking treatment in chickpeas (El-Adawy, 2002). Germination increased amount of thiamin, riboflavin, niacin and ascorbic acid in both soybean and mung bean. Mineral values in sprouted beans increased with the germination except with iron. Iron values decreased in sprouted seeds but its availability increased due to an increase in phytase activity during seed germination 24h (Bates et al., 1977; Walker and Kochhar, 1982). As germination takes place, the anti-nutritional factors are greatly decreased to insignificant levels or to nothing (Siddhuraju and Becker, 2001; El-Adawy, 2002; Ugwu and Oranye, 2006).

Lots of research work has been done on the effect of processing methods such as sprouting on bambara groundnut. However, little research has been done on the adsorption characteristics of sprouted bambara groundnut, hence this research work investigated the moisture adsorption characteristics of sprouted bambara groundnut flour.

\section{MATERIALS AND METHODS}

\section{Preparation of sprouted bambara groundnut flour}

The bambara groundnut purchased from Kuto market in Abeokuta, Ogun State was sorted, cleaned and spread in a malting chamber for 7 days to allow germination during which the nuts were sprinkle with water and turned at intervals. The germinated bambara nuts were dried in an electric oven at temperature of $45^{\circ} \mathrm{C}$ for 24 hours. After the drying, the sprouted bambara groundnuts were dry milled using grinding machine and sieved to remove shaft. The resulted flour was kept in a polythene bag for further use.

\section{Microclimate conditioning}

The required micro climate was prepared from various concentrations of sulphuric acid in creating relative humidity ranging from $20 \%-50 \%$ at room temperature, namely: $20 \%$ Relative humidity $=20 \%$ distilled water + $80 \% \mathrm{H}_{2} \mathrm{SO}_{4}, 30 \%$ Relative humidity $=30 \%$ distilled water $+70 \% \mathrm{H}_{2} \mathrm{SO}_{4,4} 40$ Relative humidity $=40 \%$ distilled water $+60 \% \mathrm{H}_{2} \mathrm{SO}_{4}, 50 \%$ Relative humidity $=50 \%$ distilled water $+50 \% \mathrm{H}_{2} \mathrm{SO}_{4}$ (Alakali and Satimehin, 2009).

\section{Determination of adsorption isotherm}

Static gravimetric method was used. $5.0 \mathrm{~g}$ of sprouted Bambara groundnut flour were weighed in triplicate into moisture pans and placed on wire gauze in the micro desiccator (Ajibola, 1986). The micro desiccators containing the samples were kept in the large desiccator at room temperature with relative humidity of $20 \%$ until constant weight was attained. The samples were weighed at 1 hour intervals until three successive readings were each less than $0.5 \%$ of the previous one. The moisture content was calculated by subtracting the initial weight of the sample from the final weight of the sample after completion of time using the data of initial moisture content and the amount of moisture gained or lost at equilibrium. The procedure was repeated for the replicate samples at 30\%, $40 \%$ and $50 \%$ relative humidity and the moisture content was also calculated in the same manner. The moisture content of the equilibrated samples on dry basis was then plotted against the relative humidity so as attain isotherm curve.

\section{Determination of equilibrium moisture content}

Equilibrium moisture content was determined by calculating the original moisture content and the known change in weight on dry basis (Oyelade et al., 2008). The relation below is used in calculating the equilibrium moisture content (EMC) of the samples.

\section{EMC = (Adsorbed moisture $/$ Weight of sample) $\mathrm{X}$ 100}

\section{Determination of water activity}

The water activity $a_{w}$ of the sample was determined from the relative humidity of the air surrounding the sample when the air and the sample are at equilibrium which is equilibrium relative humidity. The equilibrium relative humidity value was divided by 100 to get the water $\left(a_{w}\right)$ value.

\section{Mathematical Model}

The experimental equilibrium moisture content (EMC) data were processed using Microsoft Excel (2010) software and analyzed using the Henderson, Oswin and Smith models. The parameters of the models were calculated by direct non-linear 
Table 1. The mean values of adsorption isotherm of sprouted Bambara groundnut flour. Time Humidity (\%)

\begin{tabular}{lllll}
\hline (Hour) & 20 & 30 & 40 & 50 \\
\hline 0 & $5.00 \pm 0.01$ & $5.00 \pm 0.01$ & $5.00 \pm 0.04$ & $5.00 \pm 0.01$ \\
2 & $5.26 \pm 0.02$ & $5.24 \pm 0.01$ & $5.28 \pm 0.01$ & $5.31 \pm 0.01$ \\
4 & $5.26 \pm 0.02$ & $5.24 \pm 0.01$ & $5.28 \pm 0.01$ & $4.31 \pm 0.02$ \\
6 & $5.29 \pm 0.01$ & $5.31 \pm 0.01$ & $5.31 \pm 0.01$ & $5.36 \pm 0.01$ \\
8 & $5.32 \pm 0.01$ & $5.35 \pm 0.01$ & $5.36 \pm 0.01$ & $5.38 \pm 0.01$ \\
21 & $5.31 \pm 0.01$ & $5.35 \pm 0.01$ & $5.36 \pm 0.01$ & $5.38 \pm 0.01$ \\
23 & $5.32 \pm 0.01$ & $5.35 \pm 0.01$ & $5.36 \pm 0.01$ & $5.38 \pm 0.01$ \\
\hline
\end{tabular}

Table 2. Calculated moisture content and equilibrium moisture content values of sprouted bambara groundnut flour.

\section{Relative}

humidity

(\%)

\begin{tabular}{|c|c|c|c|c|c|c|c|c|c|c|}
\hline & & & & Time & (Hour) & & & Absorbed & moisture & Water \\
\hline & 0 & 2 & 4 & 6 & 8 & 21 & 23 & moisture & & activity \\
\hline 20 & 5.00 & 5.14 & 5.26 & 5.29 & 5.32 & 5.31 & 5.32 & 0.32 & 6.40 & 0.2 \\
\hline 30 & 5.00 & 5.10 & 5.24 & 5.31 & 5.35 & 5.35 & 5.35 & 0.35 & 7.00 & 0.3 \\
\hline 40 & 5.00 & 5.17 & 5.28 & 5.31 & 5.36 & 5.36 & 5.36 & 0.36 & 7.20 & 0.4 \\
\hline 50 & 5.00 & 5.19 & 5.31 & 5.36 & 5.38 & 5.37 & 5.38 & 0.38 & 7.60 & 0.5 \\
\hline
\end{tabular}

regression analysis using DATAFIT package.

\section{Henderson parameters}

This is a commonly used model and it can be expressed as it is described in equation 1.

$M_{W} \quad=\left(-\frac{\ln \left(1-a_{w}\right)}{c}\right)^{1 / n}$

where $\mathrm{C}$ and $\mathrm{n}$ are constants.

According to this model, a plot of $\ln [-\ln (1-a w)]$ versus $\ln$ Mw should give a straight line.

\section{Oswin parameters}

It is an empirical model that consists in a series expansion for sigmoid shaped curves and it was developed by Oswin, 1946. It is described in equation 2:

$$
M_{w}=C\left(\frac{a_{w}}{1-a_{w}}\right)^{n}
$$

where $\mathrm{C}$ and $\mathrm{n}$ are constants.

The Oswin equation was used to relate the moisture content of fat free dry milk and freeze dried tea up to a water activity of 0.5 (Oswin, 1946), as well as for various foods.

\section{Smith parameters}

In 1947, Smith developed an empirical model to describe the final curved portion of water sorption isotherm of high molecular weight biopolymers.

This model can be written as equation 3 :

$$
M_{w}=C_{1}+C_{2} \ln \left(1-a_{w}\right)
$$

where $\mathrm{C}_{1}$ is the quantity of water in the first sorbed fraction, and C2 is the quantity of water in the multilayer moisture fraction.

This equation could be used in the water activity range from 0.5 to 0.95 in the case of wheat desorption and for various products.

\section{RESULTS AND DISCUSSION}

\section{Moisture sorption characteristics of sprouted bambara groundnut flour}

The mean values and standard deviations of sorption isotherms of sprouted Bambara groundnut flour are presented in Table 1 . The calculated moisture content and Equilibrium Moisture Content (EMC) are presented in Table 2 at different times and relative humidity.

Sorption isotherms of sprouted Bambara groundnut flour at room temperature in the $a_{w}$ range of 0.2 to 0.5 are 


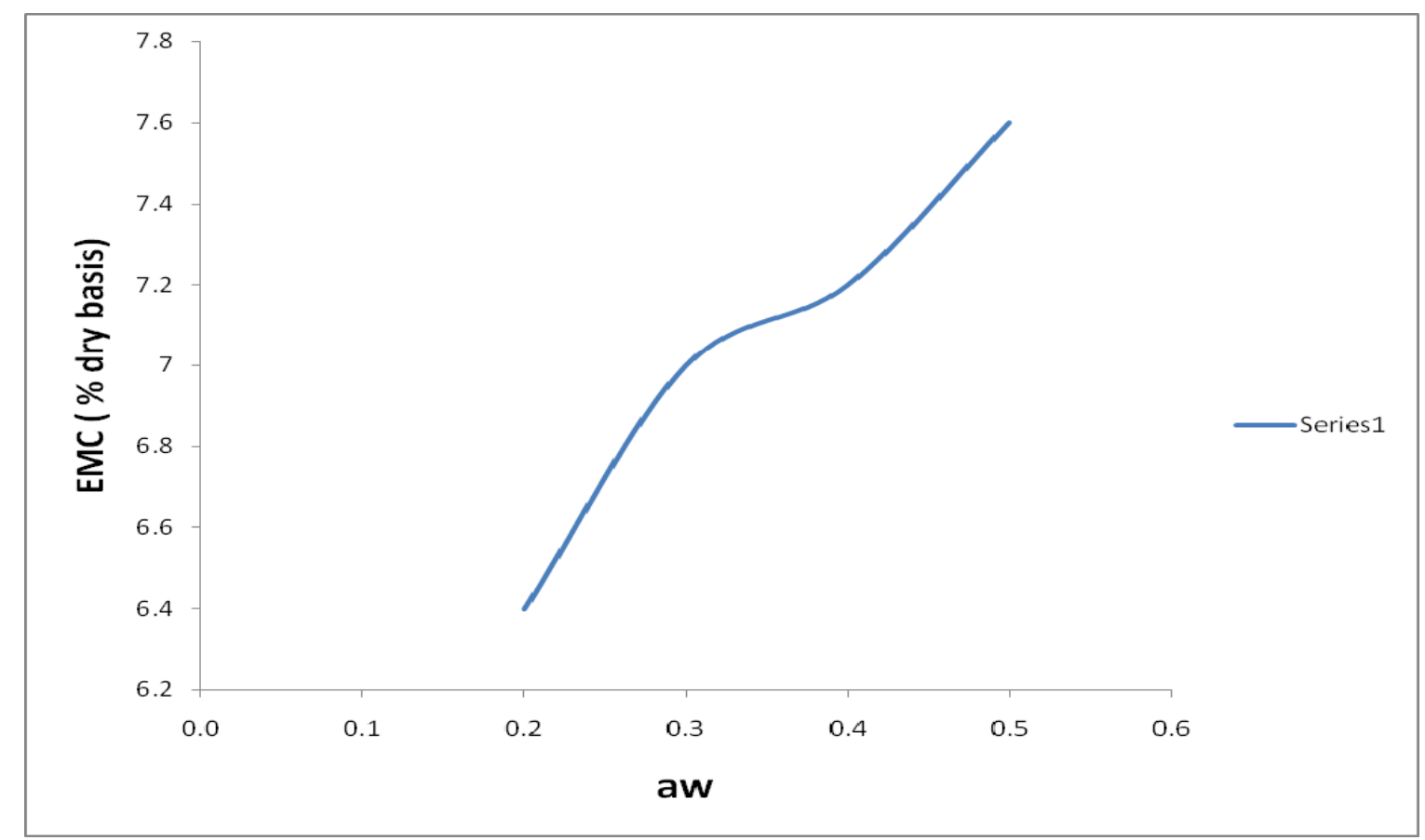

Figure 1. Equilibrium Moisture Content versus Water activity

Table 3. Parameter values for all models in adsorption of sprouted Bambara groundnut flour

Models
Henderson
A
B
$\mathrm{R}^{2}$
SE
Oswin
A
B
$\mathrm{R}^{2}$
SE
Smith
c1
c2
$\mathrm{R}^{2}$
SE

\begin{tabular}{ll} 
Values & \\
\hline & $1.28 \times 10-6$ \\
\hline 6.4979 \\
0.9736 \\
0.099 \\
\\
7.6065 \\
0.1179 \\
0.9735 \\
0.099 \\
\\
\hline 5.9799 \\
2.3996 \\
0.9438 \\
0.1452
\end{tabular}

shown in Figure 1, which follow the characteristic sigmoidal sorption isotherm (type II isotherm) according to the classification of Brunauer et al. (1940) in which the curves are concave upwards; and it takes into account the existence of multilayers at the internal surface of a material. This is the type of isotherm most commonly found in food products. The isotherm was similar to that of yam flour as reported by Oyelade et al. (2008), which was sigmoidal in shape. It was observed that the EMC increased sharply as the water activities increased.
These findings were in agreement with those of Budi and Jenshinn (2010) for the adsorption characteristics of Taro flour.

\section{Curve fitting of sorption isotherms of sprouted bambara groundnut flour}

The estimated parameters of the Henderson, Oswin and Smith models are presented in Table 3. The A value of 
Oswin model (7.6065) was greater than that of Henderson model $(1.28 \times 10-6)$. Whereas, the $B$ value of Henderson was greater than (6.4979) that of Oswin model (0.1179).

The three models have low SE values (less than 0.5) and higher $\mathrm{R}^{2}$ (higher than 0.9 ). Thus, it can be concluded that the three were well fitted for adsorption isotherms of sprouted Bambara groundnut flour. That was in close agreement with the finding of Budi and Jenshinn, (2010) for the adsorption characteristics of Taro flour. However, SE value (0.1452) of the Smith model was higher than that of Henderson and Oswin models with the same value, (0.099).

Also, Henderson and Oswin models have the same value of $R^{2}(0.97)$ greater than Smith value $(0.94)$. Therefore, the Henderson and Oswin models could be considered as the most appropriate model for the moisture adsorption isotherms of sprouted Bambara groundnut flour.

\section{CONCLUSION}

Moisture sorption isotherms of sprouted bambara groundnut flour exhibited sigmoidal shape described as type II, typical of foodstuff. The EMC values increased with increased water activity. The Henderson and Oswin models described the sorption data well over the of water activities studied in this investigation as the Henderson and Oswin model could be satisfactorily used to predict the moisture sorption isotherms of sprouted Bambara groundnut flour for water activity between $0.2-0.5$.

\section{REFERENCES}

Ajibola OO(1986). Desorption isotherms for plaintain at several temperatures.J. Food Sci. 51: 69-71

Alakali JS, Satimehin AA(2009). "Moisture adsorption characteristics of ginger (Zingiber officinale) powders". Agricultural Engineering International: the CIGRE journal. 11(186): 10-15.

Bates RP, Knapp FW, Araujo PE(1977). Protein quality of green mature, dry mature and sprouted soy-beans. J. Food Sci. 42: 271272.

Brunauer S, Deming LS, Teller E(1940). On a theory of Van der Waals adsorption of gases. J Am Chem Soc. 62 (7): 1723-1732.
Budi N, Jenshinn L(2010). Moisture sorption isotherm characteristics of taro flour. World Journal of Dairy \& Food Sciences 5 (1): 01-06.

El-Adawy TA(2002). Nutritional composition and antinutritional factors of chickpeas (Cicer arietinum L.) undergoing different cooking methods and germination. PI Food Hum. Nutr., 57: 83-97.

El-Hag N, Haard NF, Morse RE(1978). Influence of sprouting on the digestibility coefficient, trypsin inhibitor and globulin proteins of red Kidney beans. J. Food Sci., 43: 1874- 875.

Kakade ML, Evans RJ(1966). Growth inhibition of rats fed raw navy beans (Phaseolus vulgaris). J. Nutr., 90: 191-192.

Kylen AM, McCready RM(1975). Nutrients in seeds and sprouts of alfalfa, lentils, mung bean and soybeans. J. Food Sci. 40: 10081009.

Labuza TP, Kaane A, Chen JY(1985). Effect of temperature on the moisture sorption isotherms and water activity shift of two dehydrated foods. Journal of Food Science 50:385-391.

Ologhobo AO, Fetuga BL(1986). Changes in carbohydrate content of germinated cowpea. Food Chem. 20: 117-125.

Oswin CR(1946). The kinetics of package life. III. The Isotherm. J Soc Chem Ind (12): 419-421.

Oyelade OJ, Tunde-Akintunde TY, Igbeka JC(2008). Predictive equilibrium moisture content equations for yam (Dioscorea rotundata, Poir) flour and hysteresis phenomena under practical storage conditions. J. Food Engineering. 87(2): 229-235.

Rachie KO, Silvester P(1977). Grain Legumes. In: Leakey, C.L A. and Wiliany, T.B. (eds), Food Crop of the Lowland Tropics, Oxford University Press, U.K. pp 41-74.

Rizvi SSH(1995). Thermodynamics Properties of Foods in Dehydration. In: Rao, M. A. and Rizvi, S. S. H. (eds), Engineering Properties of Foods, Marcel Dekker, New York. 10-11.

Siddhuraju P, Becker K(2001). Effect of various indigenous processing methods on the galactoside and mono- and disaccharide content of an Indian tribal pulse (Mucuna prueriens var utilis). J. Sci. Food and Agric., 81: 718-725.

Smith SE(1947). The sorption of water vapour by high polymers. Journal of the

American Chemical Society. 69: 646-651.

Ugwu FM, Oranye NA(2006). Effects of some processing methods on the toxic components of African breadfruit (Treculia africana). Afr. J. Biotech. 5 (22): 2329-2333.

Walker AF, Kochhar N(1982). Effect of cooking including domestic cooking on nutritional quality of legumes. Proc. Nutr. Soc. 41: 41-51. 